\title{
ZNAJOMOŚĆ PRAWIDŁOWOŚCI ROZWOJOWYCH DZIECKA SZEŚCIOLETNIEGO PRZEZ NAUCZYCIELI KLAS I-III
}

\begin{abstract}
Abstrakt: Artykuł jest próbą omówienia badań o charakterze ewaluacyjnym, przeprowadzonych na potrzeby projektu „Sześciolatek w szkole”, współfinansowanego ze środków Unii Europejskiej w ramach Europejskiego Funduszu Społecznego. Wobec obniżenia wieku szkolnego bardzo ważna wydaje się znajomość prawidłowości rozwojowych dziecka sześcioletniego przez nauczycieli klas I-III. Posiadanie tej wiedzy pozwala na dostosowanie wymagań programowych do indywidualnych możliwości dziecka, jego potrzeb, zdolności, zainteresowań. Istotne wydają się zarówno sposoby pozyskiwania informacji na temat prawidłowości rozwojowych dziecka sześcioletniego, dostrzeżenie i zrozumienie ich znaczenia w prawidłowym funkcjonowaniu dziecka na terenie szkoły, jak i umiejętność rozwiązywania zaistniałych problemów w praktyce edukacyjnej. Tworzenie optymalnych warunków do realizacji założeń podstawy programowej, konstruowania wiedzy, nabywania umiejętności i kształtowania postaw nie jest możliwe bez wnikliwego poznania dziecka, obserwacji i analizy jego zachowań.
\end{abstract}

Słowa kluczowe: sześciolatek. prawidłowości rozwojowe, nauczyciel

Wobec obniżenia wieku szkolnego bardzo ważna wydaje się znajomość przez nauczycieli klas I-III prawidłowości rozwojowych dziecka sześcioletniego. Posiadanie tej wiedzy pozwala na dostosowanie wymagań programowych do indywidualnych możliwości dziecka, jego potrzeb, zdolności, zainteresowań. Istotne wydają się zarówno sposoby pozyskiwania informacji na temat prawidłowości rozwojowych dziecka sześcioletniego, dostrzeżenie i zrozumienie ich znaczenia w prawidłowym funkcjonowaniu dziecka na terenie szkoły, jak i umiejętność rozwiązywania zaistniałych problemów w praktyce edukacyjnej.

Dostrzegając realną potrzebę przeprowadzenia badań naukowych w środowisku nauczycieli klas I-III, powzięto myśl o przystąpieniu do realizacji projektu 
edukacyjnego kierowanego do tej grupy zawodowej. Osoby objęte badaniami to nauczyciele szkół wiejskich z powiatu lubartowskiego i łęczyńskiego - adresaci projektu „Sześciolatek w szkole”, realizowanego w roku szkolnym 2012/2013, a współfinansowanego ze środków Unii Europejskiej w ramach Europejskiego Funduszu Społecznego. W szczególności są to osoby zajmujące się kształceniem zintegrowanym, których zadaniem jest właściwe zorganizowanie procesu dydaktyczno-wychowawczego od pierwszych dni pobytu dziecka w szkole i skuteczne kontynuowanie tego procesu. Tworzenie optymalnych warunków do realizacji założeń podstawy programowej, konstruowania wiedzy, nabywania i doskonalenia umiejętności, kształtowania postaw wydaje się kluczem do edukacyjnego sukcesu.

W badaniach o charakterze ewaluacyjnym wzięło udział 40 osób. Zastosowano pisemną formę weryfikacji wiadomości i umiejętności uczestników projektu. Przed rozpoczęciem kilkunastogodzinnego cyklu zajęć (w obrębie jednego z modułów) i po ich zakończeniu do nauczycieli skierowano następujące polecenia:

- Podaj sposoby pozyskiwania informacji na temat prawidłowości rozwojowych dziecka 6-letniego.

- Określ podstawowe właściwości rozwojowe dziecka 6-letniego. Jak wykorzystasz posiadaną wiedzę o dziecku w praktyce?

- Wskaż problem natury społecznej, który ujawnia się najczęściej w kontaktach rówieśniczych na progu edukacji szkolnej. Zaproponuj co najmniej dwa sposoby rozwiązania tego problemu.

- Wskaż problem natury emocjonalnej, który najczęściej dotyczy dzieci na progu edukacji szkolnej. Zaproponuj co najmniej dwa sposoby rozwiązania tego problemu.

Przyjęto, że umiejętność poszukiwania informacji i poznanie właściwości rozwojowych dziecka 6-letniego są podstawą do rozwiązywania problemów w praktyce edukacyjnej. Mając na uwadze pierwsze polecenie skierowane do nauczycieli, można stwierdzić, że udało się ustalić sposoby pozyskiwania informacji na temat prawidłowości rozwojowych dziecka 6-letniego (tab. 1).

Nauczyciele dostrzegają możliwość poznania właściwości rozwojowych dziecka poprzez obserwowanie go, rozmowę z nim, analizę wytworów pracy. „Bycie z dzieckiem", a nie obok niego, przynosi znaczące rezultaty i jest najlepszą formą poznania go. Nikt bowiem nie zna tak dobrze potrzeb, oczekiwań, zainteresowań dziecka, jak ono samo. Wnikliwe poznanie dziecka jest niewątpliwie wynikiem rzetelnej obserwacji, szczerej wymiany myśli, analizy osiąganych efektów pracy.

Znaczące wydają się również te działania nauczyciela, które bazując na posiadanych przez niego kompetencjach sprzyjają rozwojowi dziecka i w rezultacie efektywniejszej pracy pedagogicznej. Wymienić tu można: wywiad z rodzicami, 
diagnozę rozwoju dziecka na początku klasy I, studiowanie literatury i pogłębianie wiedzy, pozyskiwanie informacji od służb medycznych. Coraz większego znaczenia nabiera wymiana doświadczeń w komunikacji bezpośredniej z innymi nauczycielami. Okazją do tego jest uczestnictwo w różnorodnych formach doskonalenia zawodowego. Szkoda tylko, że nauczyciele tak rzadko korzystają z informacji o gotowości szkolnej, udostępnianych przez przedszkole. Wydaje się, że zachowanie spójności i ciągłości oddziaływań edukacyjnych podejmowanych przez przedszkole, a następnie szkołę byłoby w pełni uzasadnione.

Tab. 1. Zestawienie wyników w badaniach początkowych i końcowych gromadzenie informacji

\begin{tabular}{|l|r|r|r|r|}
\hline \multirow{2}{*}{$\begin{array}{c}\text { Sposoby pozyskiwania informacji na temat pra- } \\
\text { widłowości rozwojowych dziecka 6-letniego }\end{array}$} & \multicolumn{2}{c|}{$\begin{array}{c}\text { Badania } \\
\text { początkowe }\end{array}$} & \multicolumn{2}{c|}{$\begin{array}{c}\text { Badania } \\
\text { końcowe }\end{array}$} \\
\cline { 2 - 5 } & $\mathrm{N}$ & $\%$ & $\mathrm{~N}$ & $\%$ \\
\hline Obserwacja dziecka & 30 & 75,0 & 37 & 92,5 \\
\hline Wywiad z rodzicami & 26 & 65,0 & 26 & 65,0 \\
\hline Diagnoza rozwoju dziecka na początku kl. I & 20 & 50,0 & 28 & 70,0 \\
\hline Literatura zawarta (w tym książki z psychologii rozwojowej) & 16 & 40,0 & 21 & 52,5 \\
\hline Informacje od pielęgniarki, lekarza & 8 & 20,0 & 8 & 20,0 \\
\hline Rozmowa z dzieckiem & 6 & 15,0 & 19 & 47,5 \\
\hline Analiza wytworów dziecięcych (w tym rysunków) & 6 & 15,0 & 11 & 27,5 \\
\hline Internet & 3 & 7,5 & 11 & 27,5 \\
\hline Rozmowa z nauczycielami przedszkola & 3 & 7,5 & 5 & 12,5 \\
\hline Czasopisma & 3 & 7,5 & 5 & 12,5 \\
\hline $\begin{array}{l}\text { Informacja o gotowości szkolnej udostępniana przez przed- } \\
\text { szkole }\end{array}$ & 2 & 5,0 & 13 & 32,5 \\
\hline Kursy, warsztaty i szkolenia (w tym rady pedagogiczne) & 2 & 5,0 & 12 & 30,0 \\
\hline Informacje od pedagoga szkolnego & 2 & 5,0 & 6 & 15,0 \\
\hline Własna wiedza i doświadczenie & 2 & 5,0 & 5 & 12,5 \\
\hline Opinia poradni psychologiczno-pedagogicznej & 2 & 5,0 & 3 & 7,5 \\
\hline Rozmowa z nauczycielami klas I-III & 1 & 2,5 & 18 & 45,0 \\
\hline Wyniki najnowszych badań naukowych & 1 & 2,5 & 10 & 25,0 \\
\hline Studia podyplomowe & 2,5 & 5 & 12,5 \\
\hline Zajęcia z psychologii rozwojowej & 2,5 & 1 & 2,5 \\
\hline Rozmowy z fachowcami w danej dziedzinie & 0,0 & 7 & 17,5 \\
\hline Bezpośrednie poznanie środowiska życia dziecka & 0,0 & 1 & 2,5 \\
\hline
\end{tabular}

Źródło: opracowanie własne 
Tab. 2. Zestawienie wyników w badaniach początkowych i końcowych właściwości rozwojowe

\begin{tabular}{|c|c|c|c|c|}
\hline \multirow{2}{*}{$\begin{array}{l}\text { Właściwości rozwojowe } \\
\text { dziecka 6-letniego }\end{array}$} & \multicolumn{2}{|c|}{$\begin{array}{c}\text { Badania } \\
\text { początkowe }\end{array}$} & \multicolumn{2}{|c|}{$\begin{array}{l}\text { Badania } \\
\text { końcowe }\end{array}$} \\
\hline & $\mathrm{N}$ & $\%$ & $\mathrm{~N}$ & $\%$ \\
\hline Ogólna sprawność fizyczna & 9 & 22,5 & 28 & 70,0 \\
\hline Wysoki poziom czynności samoobsługowych & 8 & 20,0 & 24 & 60,0 \\
\hline $\begin{array}{l}\text { Coraz większa zdolność koncentracji uwagi na wykonywanej } \\
\text { czynności }\end{array}$ & 8 & 20,0 & 19 & 47,5 \\
\hline Rozwój mowy & 7 & 17,5 & 25 & 52,5 \\
\hline Podejmowanie współpracy w grupie rówieśniczej & 7 & 17,5 & 13 & 32,5 \\
\hline Znaczna ruchliwość wynikająca z potrzeby aktywności fizycznej & 5 & 12,5 & 28 & 70,0 \\
\hline Coraz wyższy poziom sprawności manualnej & 5 & 12,5 & 14 & 35,0 \\
\hline Nawiązywanie kontaktów rówieśniczych & 4 & 10,0 & 26 & 65,0 \\
\hline $\begin{array}{l}\text { Tendencja do wybierania zabawy jako podstawowej formy ak- } \\
\text { tywności }\end{array}$ & 4 & 10,0 & 25 & 52,5 \\
\hline Rozumienie poleceń nauczyciela i reagowanie na nie & 4 & 10,0 & 22 & 55,0 \\
\hline Stale doskonalona sprawność grafomotoryczna & 4 & 10,0 & 19 & 47,5 \\
\hline Wyższy poziom samodzielności & 2 & 5,0 & 26 & 65,0 \\
\hline $\begin{array}{l}\text { Ciekawość poznawcza i wynikająca z niej potrzeba doświad- } \\
\text { czania świata przy pomocy zmysłów }\end{array}$ & 2 & 5,0 & 24 & 60,0 \\
\hline Sygnalizowanie potrzeb & 2 & 5,0 & 17 & 42,5 \\
\hline Rosnąca stabilność emocjonalna & 2 & 5,0 & 16 & 40,0 \\
\hline $\begin{array}{l}\text { Umiejętność radzenia sobie w określonych sytuacjach społecz- } \\
\text { nych }\end{array}$ & 2 & 5,0 & 14 & 35,0 \\
\hline Myślenie konkretno-obrazowe, operacyjne & 2 & 5,0 & 12 & 30,0 \\
\hline Coraz lepsza koordynacja wzrokowo-ruchowa & 1 & 2,5 & 23 & 57,5 \\
\hline Zdolność zapamiętywania na wysokim poziomie & 1 & 2,5 & 21 & 52,5 \\
\hline Obniżona płynność i dokładność ruchów & 1 & 2,5 & 18 & 45,0 \\
\hline Spontaniczność & 1 & 2,5 & 15 & 37,5 \\
\hline Egocentryzm dziecięcy & 1 & 2,5 & 12 & 30,0 \\
\hline Umiejętność analizy i syntezy wyrazowej & 1 & 2,5 & 12 & 30,0 \\
\hline Coraz częściej ujawniane reakcje adekwatne do sytuacji & 0 & 0,0 & 18 & 45,0 \\
\hline Synkretyzm (spostrzeganie globalne) & 0 & 0,0 & 13 & 32,5 \\
\hline $\begin{array}{l}\text { Słowne wyrażanie sprzeciwu zamiast płaczu czy rzucania za- } \\
\text { bawkami }\end{array}$ & 0 & 0,0 & 12 & 30,0 \\
\hline $\begin{array}{l}\text { Dostrzeganie związków przyczynowo-skutkowych w sytuacjach } \\
\text { z życia codziennego, w opowiadaniu }\end{array}$ & 0 & 0,0 & 8 & 20,0 \\
\hline
\end{tabular}

Źródło: opracowanie własne 
Drugie sformułowane dla nauczycieli polecenie wymagało określenia podstawowych właściwości rozwojowych dziecka 6-letniego. Ponadto oczekiwano wskazania sposobów wykorzystania wiedzy o dziecku w praktyce. Zestawienie tabelaryczne prezentujące wskazane przez badanych właściwości rozwojowe dziecka zamieszczone zostało w tab. 2.

Nauczyciele uwzględnili wszystkie sfery rozwojowe dziecka. Początkowo wielu z nich (ok. 80 \%) wymieniało je tylko, wykazując ogólną znajomość zagadnienia, ale nie podawało zbyt wielu właściwości rozwojowych typowych dla 6-latka. Jako częsty przykład można podać taki zestaw wypowiedzi:

- rozwój poznawczo-umysłowy, intelektualny (mowa i myślenie, pamięć i uwaga, gotowość do nauki czytania i pisania oraz liczenia),

- rozwój fizyczny (motoryka mała i duża),

- rozwój społeczny (kontakty rówieśnicze, czynności samoobsługowe, samodzielność),

- rozwój emocjonalny,

- motywacja do podjęcia działań.

Wszystko to wskazuje, jak ważne jest określanie podstawowych właściwości rozwojowych dziecka i wykorzystanie tej wiedzy w praktyce, przy pełnym zrozumieniu potrzeb kilkulatka i jego ograniczeń wynikających z racji wieku czy uwarunkowań środowiskowych.

Istotne jest, by nauczyciele obserwowali i analizowali zachowania dziecka, co pozwala na uszczegółowienie wypowiedzi - podawanie konkretnych właściwości rozwojowych dziecka w sferze psychicznej, fizycznej, społecznej, emocjonalno-motywacyjnej (tab. 2) - oraz skuteczne użytkowanie zasobu wiedzy i doświadczeń.

Warto zwrócić uwagę na najczęściej podawane sposoby wykorzystania posiadanej wiedzy o dziecku w praktyce, jakimi są:

- $\quad$ właściwa, pogłębiona diagnoza dziecka na początku klasy I,

- założenie indywidualnych kart obserwacji rozwoju dziecka,

- skuteczne planowanie i organizacja pracy dydaktyczno-wychowawczej,

- przygotowanie się do zajęć - organizacja przestrzeni, przybory i materiały, opracowywanie atrakcyjnych dla dzieci kart pracy,

- rozwijanie zainteresowań, zdolności - projektowanie dodatkowych zajęć dla dzieci uzdolnionych,

- opracowanie serii zajęć wyrównawczych dla dzieci z deficytami,

- dostosowanie proponowanych dziecku form aktywności do jego możliwości rozwojowych; przeplatanie ze sobą różnych form aktywności,

- rozbudzanie motywacji do nauki (tabele motywacyjne z symbolami graficznymi lub naklejkami, nagrody, pochwały). 
Wskazywanie problemu natury społecznej, który ujawnia się najczęściej w kontaktach rówieśniczych na progu edukacji szkolnej, i poszukiwanie sposobów jego rozwiązania - to kolejne zadanie, jakie postawiono przed nauczycielami klas I-III. Wśród odpowiedzi osób badanych przy toczyć można następujące ich przykłady ujęte w zestawieniu tabelarycznym.

Tab. 3. Zestawienie wyników w badaniach początkowych i końcowych problem społeczny

\begin{tabular}{|l|l|}
\hline \multicolumn{1}{|c|}{ Problem natury społecznej } & \multicolumn{1}{|c|}{ Przykładowe rozwiązania problemu } \\
\hline $\begin{array}{l}\text { Nieprzestrzeganie zasad i norm } \\
\text { społeczno-moralnych obowią- } \\
\text { zujących w szkole i w klasie }\end{array}$ & $\begin{array}{l}\text { ułożenie kontraktu (umowy, regulaminu, kodeksu) przy } \\
\text { zaangażowaniu wszystkich zainteresowanych osób; } \\
\text { poświadczenie jego mocy własnoręcznym podpisem, od- } \\
\text { ciskiem dłoni itp.; } \\
\text { cykliczna ocena zachowań uczniów w kategoriach pożą- } \\
\text { dane-niepożądane; } \\
\text { nagrody za dobre zachowanie (pochwała jako motywacja } \\
\text { werbalna, symbole graficzne, rysunkowe eksponowane } \\
\text { na forum klasy i przyznawane nieodwołalnie); } \\
\text { ponoszenie konsekwencji za nieodpowiednie zachowa- } \\
\text { nie (np. chwila odosobnienia-karne krzesło) }\end{array}$ \\
\hline $\begin{array}{l}\text { Nawiązywanie kontaktów z ró- } \\
\text { wieśnikami }\end{array}$ & $\begin{array}{l}\text { organizowanie różnych zabaw, zmiany miejsc w ławkach, } \\
\text { praca w zespołach; } \\
\text { angażowanie grupy w pomoc dziecku, które ma proble- } \\
\text { my z adaptacją w środowisku szkolnym }\end{array}$ \\
\hline $\begin{array}{l}\text { Obniżony poziom umiejętno- } \\
\text { ści współpracy i współdziała- } \\
\text { nia w grupie }\end{array}$ & $\begin{array}{l}\text { naprzemienne stosowanie losowego, celowego i swobod- } \\
\text { nego doboru dzieci do zespołów pracujących nad zada- } \\
\text { niem; } \\
\text { częste angażowanie dzieci w pracę grupową; } \\
\text { przydział funkcji i zlecanie zadań stosownie do umie- } \\
\text { jętności dziecka }\end{array}$ \\
\hline $\begin{array}{l}\text { Brak integracji grupy, izolowa- } \\
\text { nie dzieci o odmiennym wy- poglądach, zachowa- } \\
\text { niu }\end{array}$ & $\begin{array}{l}\text { poznanie się przez wspólne zabawy i gry integracyjne, } \\
\text { snucie opowieści; } \\
\text { stopniowe przejście od zabawy do nauki; } \\
\text { znalezienie mocnej strony każdego dziecka i korzysta- } \\
\text { nie z zasobów jego talentu przy wykonywaniu konkret- } \\
\text { nych zadań; } \\
\text { angażowanie grupy w pomoc dziecku, które ma proble- } \\
\text { my z adaptacją w środowisku szkolnym; } \\
\text { wyznaczanie dzieciom znaczących ról w klasie (asystent } \\
\text { nauczyciela, dyżurny) }\end{array}$ \\
\hline
\end{tabular}




\begin{tabular}{|l|l|}
\hline $\begin{array}{l}\text { Obniżony poziom samodziel- } \\
\text { ności dziecka }\end{array}$ & $\begin{array}{l}\text { stwarzanie sytuacji wymagających samodzielności; } \\
\text { zapoznanie dziecka ze sposobem wykonywania danej } \\
\text { czynności (pokaz, instrukcja), wspieranie go w wykony- } \\
\text { waniu jej połączone z celowym zmniejszaniem zakresu } \\
\text { udzielanej pomocy; } \\
\text { docenianie wysiłku dziecka, niewyręczanie go w czynno- } \\
\text { ściach samoobsługowych, zachęcanie do treningu; } \\
\text { konsekwencja w postępowaniu względem dziecka; } \\
\text { wdrażanie do dbałości o siebie i własne stanowisko pra- } \\
\text { cy, poszanowanie swojej i cudzej własności; } \\
\text { rozmowa z rodzicami-opiekunami dziecka w celu przed- } \\
\text { stawienia problemu i ewentualnych sposobów przeciw- } \\
\text { działania bezradności w sytuacjach życia społecznego; } \\
\text { wybór i opracowanie utworów literackich (wierszy, opo- } \\
\text { wiadań, bajek, baśni) prezentujących zalety bycia samo- } \\
\text { dzielnym }\end{array}$ \\
\hline
\end{tabular}

Źródło: opracowanie własne

Problemem społecznym, który ujawnia się najczęściej po przekroczeniu progu edukacyjnego pomiędzy przedszkolem a szkołą, jest obniżony poziom samodzielności dziecka będącego w fazie nieustannego, okazjonalnego i celowego uczenia się. Problem ten mieści się w normie rozwojowej dziecka sześcioletniego, które nabywa umiejętność radzenia sobie w sytuacjach życia codziennego, w środowisku szkolnym i rodzinnym. Podejmowanie działań umożliwiających poznawanie siebie - swoich możliwości i ograniczeń, praw i obowiązków, w niedalekiej przyszłości poskutkuje samodzielnością w uczeniu się, co w zakresie kompetencji osobistych jest kluczem do sukcesu edukacyjnego i społecznego.

W dalszej kolejności wymienić należy brak integracji grupy, skutkujący izolowaniem dzieci o odmiennym wyglądzie, poglądach i zachowaniu. Niełatwe okazuje się ponadto przestrzeganie zasad i norm społeczno-moralnych obowiązujących w szkole i w klasie oraz umiejętność współpracy i współdziałania w grupie. Stosunkowo najmniej problematyczne okazuje się nawiązywanie kontaktów rówieśniczych.

Wskazywanie problemu natury emocjonalnej, który najczęściej dotyczy dzieci na progu edukacji szkolnej, i proponowanie co najmniej dwu sposobów rozwiązania tego problemu przyniosło rezultaty przedstawione w tab. 4 .

Zdaniem nauczycieli klas I-III najczęstszym problemem emocjonalnym jest nadwrażliwość emocjonalna wywołująca reakcje nieadekwatne do sytuacji, płaczliwość czy nieumiejętne przyjmowanie porażki. Równie istotne okazuje się bezpieczeństwo dziecka, zarówno w odniesieniu do osób z najbliższego otoczenia, jak i poznawania czy eksploracji przestrzeni szkolnej. Zapewnienie „przyjaznego otoczenia” pozwoli na odkrywanie własnych możliwości i podejmowanie zadań bez 
lęku o ich poprawne wykonanie. Ten rodzaj aktywności będzie motywowany ciekawością poznawczą i bez względu na drogę dochodzenia do rozwiązań - będzie mieć charakter poznawczy.

Tab. 4. Zestawienie wyników w badaniach początkowych i końcowych - problem emocjonalny

\begin{tabular}{|c|c|}
\hline Problem natury emocjonalnej & Przykładowe rozwiązania problemu \\
\hline Brak poczucia bezpieczeństwa & $\begin{array}{l}\text { zaangażowanie i wsparcie ze strony nauczyciela; } \\
\text { ustalenie i przestrzeganie rytmu dnia; } \\
\text { krótkie pożegnanie dziecka z opiekunem; } \\
\text { ustalenie zasad odbioru dziecka ze szkoły przez osoby } \\
\text { do tego uprawnione; } \\
\text { możliwość przyniesienia w wyznaczonym dniu tygo- } \\
\text { dnia ulubionej zabawki; } \\
\text { organizacja bezpiecznej przestrzeni w klasie szkolnej; } \\
\text { podejmowanie tematów bezpieczeństwa dziecka w róż- } \\
\text { nych sytuacjach z życia codziennego }\end{array}$ \\
\hline $\begin{array}{l}\text { Brak wiary we własne możliwo- } \\
\text { ści, niska samoocena, lęk przed } \\
\text { zadaniem }\end{array}$ & $\begin{array}{l}\text { indywidualizacja pracy z dzieckiem; } \\
\text { stopniowanie trudności; } \\
\text { wzmacnianie poczucia własnej wartości, np. poprzez } \\
\text { przydzielanie odpowiedzialnych zadań; } \\
\text { ocenianie wkładu pracy, a nie tylko efektu końcowego; } \\
\text { wzmacnianie poczucia sukcesu }\end{array}$ \\
\hline $\begin{array}{l}\text { Nadwrażliwość emocjonalna, re- } \\
\text { akcje nieadekwatne do sytuacji, } \\
\text { nieumiejętne przyjmowanie po- } \\
\text { rażki, płaczliwość }\end{array}$ & $\begin{array}{l}\text { rozmowa z dzieckiem; } \\
\text { zastosowanie pracy z obrazkiem i historyjką obrazkową; } \\
\text { snucie opowieści realistycznych i fantastycznych; } \\
\text { stwarzanie sytuacji wymagających radzenia sobie w sy- } \\
\text { tuacjach szkolnych; } \\
\text { nazywanie uczuć i emocji, prezentowanie ich w scen- } \\
\text { kach dramowych i omówienie okoliczności ich zaist- } \\
\text { nienia }\end{array}$ \\
\hline
\end{tabular}

Źródło: opracowanie własne

We wszystkich omawianych obszarach znajomość przez nauczycieli klas I-III prawidłowości rozwojowych dziecka sześcioletniego i poszukiwanie rozwiązań pojawiających się problemów pozwoli na lepszy start szkolny sześciolatków. Wydaje się, że w odniesieniu do wprowadzanych przez Ministerstwo Edukacji Narodowej zmian dotyczących obniżenia wieku rozpoczęcia obowiązku szkolnego każdy przejaw refleksji jest cenny. 


\title{
KNOWLEDGE OF A SIX YEAR OLD CHILD'S DEVELOPMENTAL REGULARITIES BY TEACHERS OF GRADES I-III
}

\begin{abstract}
This article is an attempt to discuss the evaluative research conducted for the purpose of the project „A six-year old in school”, co-financed by the European Union Social Fund. In the context of lowering the school starting age it seems very important for teachers of grades I to III to know the developmental regularities of a six-year-old child. The possession of this knowledge facilitates the adjustment of the curriculum requirements to the child's individual capabilities, needs, abilities, and interests. Particularly significant seem both the ways of obtaining information on the developmental regularity of the six-year-old child, noticing and understanding their importance to the proper functioning of the child in school, and the ability to solve problems occurring in the educational practice. The creation of optimal conditions for the realization of the curriculum objectives, construction of knowledge, acquisition of skills and shaping of attitudes is not possible without a thorough knowledge of the child, observation and analysis of his or her behavior.
\end{abstract}

Key words: six year old child, developmental regularities, teacher 